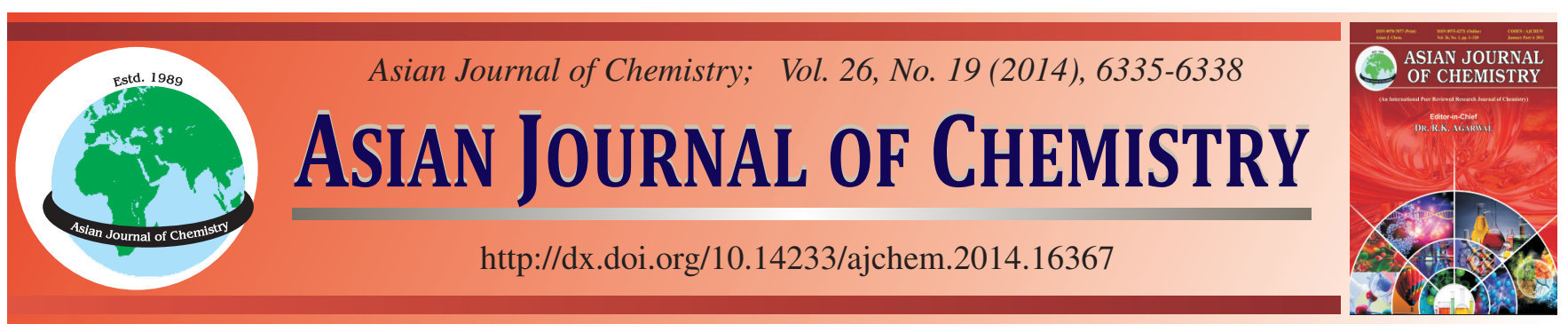

\title{
Treatment of Cattle Slaughter House Wastewater by Electrocoagulation Method Using Aluminium Electrodes
}

\author{
Muhammad Kaleem Khosa ${ }^{1, *}$, Muhammad Asghar $\mathrm{Jamal}^{1}{ }^{1}$, Khalid Mahmood Zia ${ }^{2}$, \\ Muhammad Jawad SAIF ${ }^{2}$, FAZAL-Ur-Rehman ${ }^{2}$, TANVer Hussain BoKhari and Mohsin Raza ${ }^{1}$
}

${ }^{1}$ Department of Chemistry, Government College University, Faisalabad 38000, Pakistan

${ }^{2}$ Department of Applied Chemistry, Government College University, Faisalabad 38000, Pakistan

*Corresponding author: Tel: +92 300 6345869; E-mail: mkhosapk@yahoo.com

Received: 14 September 2013;

Accepted: 24 December 2013;

Published online: 16 September 2014;

AJC-15913

\begin{abstract}
Electrocoagulation technique was used for the treatment of cattle slaughter house wastewater with the purpose of lowering the chemical oxygen demand concentration (3500 $\mathrm{mg} \mathrm{L}^{-1}$ ) and turbidity (290 nephelometric turbidity units) to levels below the permitted directdischarge limits. All the experiments were carried out in batch mode by using sacrificial anodes (Al-electrodes) corrode to release active coagulant flocs usually aluminium cations into the solution. During electrolytic reactions hydrogen gas evolved at the cathode. The effect of different parameters such as $\mathrm{pH}$, electrolyte concentration and current density was studied. The evaluation of treatment efficiency (\%) was determined by measuring both the reduction of chemical oxygen demand and residual turbidity. Under optimum conditions, the removal efficiency was 93 and $96 \%$ for chemical oxygen demand and turbidity respectively at $7.8 \mathrm{pH}, 0.001 \mathrm{~mol} \mathrm{~L}^{-1}$, electrocoagulant dose and $2.16 \mathrm{~A} / \mathrm{m}^{2}$ current density. It is concluded that the electro-coagulation process has potential to be utilized for the cost-effective treatment of wastewater specially using aluminium electrodes in terms of high removal efficiencies and operating cost.
\end{abstract}

Keywords: Aluminium electrode, chemical oxygen demand, Cattle slaughterhouse wastewater, Electrocoagulation.

\section{INTRODUCTION}

The reuse of wastewater has become an absolute necessity. Demands to the cleaning industrial and domestic wastewater to avoid environmental pollution and especially contamination of pure water resources are becoming national and international issues. Innovative, low-cost and effective methods of purifying and cleaning wastewater before discharging into any other water systems are needed ${ }^{1}$. A growing research interest is reported on the treatment of various wastewater types: metal processing wastewaters ${ }^{2}$, semiconductor production wastewater $^{3}$, textile dyeing wastewaters ${ }^{4-8}$, tannery wastewater pretreatment ${ }^{9-13}$, olive mill wastewater ${ }^{14-16}$, urban wastewater ${ }^{17}$ and organics removal from poultry slaughter house wastewaters ${ }^{18}$. Electrocoagulation has also been used to treat the landfill leachate by some researchers ${ }^{19-22}$. Slaughtering of animals and the production of related products are coupled with the need for plenty of clean water and the emission of polluted water that has to be purified before it can be discharged into the drainage system. Therefore, slaughter house processes in industrialized countries are governed by strict legislation to protect public health and environment. Wastewater from a cattle slaughter house is a mixture of the processing water from both the slaughtering line and the cleaning of the guts, which causes a large variation in the concentration of organic matter. The main pollutant in slaughter house effluents is organic matter. The contributors of organic load to these effluents are paunch, feces, fat and lard, undigested food, blood, suspended material, urine, loose meat, soluble proteins, excrement and colloidal particles $^{23}$. The treatment of slaughter house wastewater by anaerobic methods ${ }^{24-26}$ and hybrid systems ${ }^{27}$ have been intensively studied. Coagulation of slaughter house wastewater has also been studied with maximum chemical oxygen demand removal efficiency of $45-75 \%$ by adding aluminum salts and polymer compounds as supporting electrolytes ${ }^{28}$. Using electricity to treat water was first proposed in UK in 1889. The electrocoagulation of drinking water was first applied on large scale in the US in $1946^{29}$. Electrocoagulation is also known as radio frequency diathermy or short wave electrolysis. A wide range of wastewater treatment techniques are known which includes biological processes and physiochemical processes. These include electrocoagulation, electroflotation (EF), electrooxidation $(\mathrm{EO})^{30}$. Electrocoagulation due to some advantages over chemical coagulation is becoming a popular process to be used for wastewater treatment. Electrocoagulation is an effective process for the destabilization of finally dispersed particles by removing hydrocarbon greases, suspended solids and heavy metals from different types of wastewater ${ }^{31}$. 
Electrocoagulation involves dissolution of metal from the anode with simultaneous formation of hydroxyl ions and hydrogen gas occurring at the cathode. (From the anode) into the solution, reacting with the hydroxyl ions (from the aluminium or iron is usually used as electrodes and there cations are generated by dissolution of sacrificial anodes upon the application of direct current ${ }^{32}$. The metal ions generated are hydrolyzed in the electrochemical cell to produce metal hydroxide ions according to reactions 1-3 and only neutral $\mathrm{M}(\mathrm{OH})_{3}$ has a very low solubility mainly at $\mathrm{pH}$ values in the range 6-7. Metal species react with negatively charged particles in the water to form flocs. The in situ generation of coagulants means that electrocoagulation processes do not require the addition of any chemicals. The gases produced during the electrolysis of water and metal dissolution allow the resulting flocs to float $^{7}$.

$$
\begin{gathered}
\mathrm{Al} \rightarrow \mathrm{Al}^{3+}{ }_{(\mathrm{aq})}+3 \mathrm{e}^{-} \\
3 \mathrm{H}_{2} \mathrm{O}+3 \mathrm{e}^{-} \rightarrow 3 / 2 \mathrm{H}_{2(\mathrm{~g})}+3 \mathrm{OH}^{-} \\
\mathrm{Al}^{3+}(\mathrm{aq})+3 \mathrm{H}_{2} \mathrm{O} \rightarrow \mathrm{Al}(\mathrm{OH})_{3}+3 \mathrm{H}^{+}
\end{gathered}
$$

The wastewater from cattle slaughter houses passed through the electrocoagulation process by using a specific anode made from aluminum. The purpose of this work was to investigate the feasibility of treating cattle-slaughter house wastewater by electrocoagulation to achieve the required legal direct-discharge limit of chemical oxygen demand ${ }^{33,34}$ which is $250 \mathrm{mg} \mathrm{L}^{-1}$. The influence of the operating variables such as $\mathrm{pH}$, current density and supporting electrolyte $\left(\mathrm{Na}_{2} \mathrm{SO}_{4}\right)$ dosage on the removal efficiencies of chemical oxygen demand and turbidity were also determined.

\section{EXPERIMENTAL}

The experimental setup was mainly consisted of a beaker of $1.5 \mathrm{~L}$ as a reactor to hold a sample of $1.2 \mathrm{~L}$ as shown in Fig. 1.Two pyrex glass strips were attached to the inner phase of the glass beaker as baffles, to create turbulence and facilitate proper mixing of the sample. Three pair of aluminium electrode plates as anode and cathode, each with an active surface area of $16 \mathrm{~cm}^{2}$, were arranged at a spacing of $4 \mathrm{~cm}$ and connected to an external power source. DC power source, a rheostat to keep the current invariant, an ammeter and volt meter to read the values of current and voltage, a magnetic bar stirrer to mix

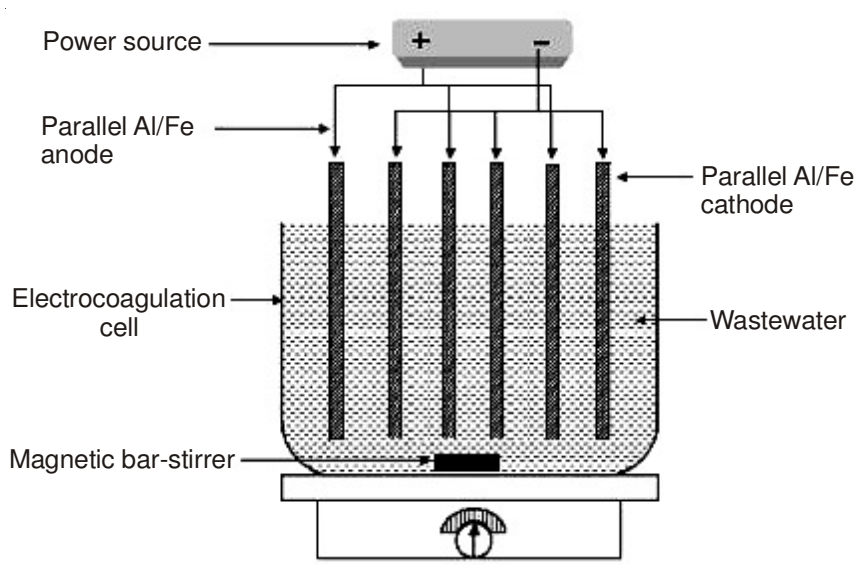

Fig. 1. Schematic diagram of experimental setup the solution and reduce the mass transfer limitation during the reaction were used. A switch was used to change the polarity of electrodes to reduce the passivation phenomenon that usually occurs during the process at cathode and impedes the oxidation and reduction reactions.

Analytical procedures: For all experiments, the physicochemical parameters were analyzed, by the methods described in the standard methods for the examination of wastewater ${ }^{35}$. A pH meter manufactured by thermo orion of model $550 \mathrm{~A}$ was used for the determination of $\mathrm{pH}$. Although the pure water is described as colorless liquid, it is unusual for natural water to have no color. The color of water should be determined only after suspended matter has been removed by centrifugation. Removal of suspended matter by filtration is not permissible because filters may absorb some of the color. Color may be determined by comparison with white color discs. Conductivity is quite important to know something about the nature of water. The specific conductance is a measure of total concentration of ionic solutes and thus TDS. The specific conductance of a solution is usually expressed as $\mathrm{mS} / \mathrm{cm}$ or $\mu \mathrm{S} / \mathrm{cm}$. chemical oxygen demand was calculated by closed reflux, colorimetric method. chemical oxygen demand concentration was measured colorimetrically using a DR/2000 spectrophotometer ${ }^{34}$.

\section{RESULTS AND DISCUSSION}

The effect of parameters such as $\mathrm{pH}$, current density and supporting electrolyte dosage have been evaluated under specific conditions for a constant reaction time. The removal efficiency (\%) after electrocoagulation wastewater was calculated as:

$$
\mathrm{RE} \%=\left(\mathrm{C}_{\mathrm{o}}-\mathrm{C} / \mathrm{C}_{\mathrm{o}}\right) \times 100
$$

where $\mathrm{C}_{\mathrm{o}}$ and $\mathrm{C}$ are the concentrations before and after electrocoagulation, respectively, in $\mathrm{mg} / \mathrm{L}$. The $\mathrm{pH}$ value of all the samples are within the limit (7.0-7.9) it means that acidity characteristics of the samples are satisfactory. The observed conductance values of all samples are in the range of 173.7$126 \mu \mathrm{S} \mathrm{cm}^{-1}$ which is in permissible range. Dark color of wastewater may be due to presence of large quantities of organic chemicals, such as blood, undigested food, feces, fat and lard. Color of the sample of wastewater disappears as the treatment time increases.

Effect of pH: The $\mathrm{pH}$ of raw wastewater can have either a positive or a negative influence on the treatment efficiency as it affects the stability of various hydroxide species that are formed. Likewise, a change in $\mathrm{pH}$ can modify the surface charge of particles and greatly influence the removal of colloidal dispersed organics from solution ${ }^{35} \cdot \mathrm{Al}^{3+}$ ions on hydrolysis may generate hydroxyaluminum species. At $\mathrm{pH}<4$ aqueous complex $\mathrm{Al}\left(\mathrm{H}_{2} \mathrm{O}\right)_{6}{ }^{3+}$ is predominant. Between $\mathrm{pH} 5$ and 6 the predominant hydrolysis products are $\mathrm{Al}(\mathrm{OH})_{2}{ }^{+}$and $\mathrm{Al}(\mathrm{OH})^{2+}$; between $\mathrm{pH} 5.2$ and 8.8 the solid $\mathrm{Al}(\mathrm{OH})_{3}$ is most prevalent; and above $\mathrm{pH} 9$ the soluble species $\mathrm{Al}(\mathrm{OH})_{4}{ }_{4}^{-}$is the predominant and the only species ${ }^{36,37}$ present above $\mathrm{pH} 10$. The removal efficiency increased with an increase of $\mathrm{pH}$ from an acidic $\mathrm{pH}$ to basic and subsequently dropped at $\mathrm{pH} 9$ because the coagulant could not be produced efficiently at low and high $\mathrm{pH}$ values ${ }^{23}$. Analysis of the graphs revealed that the chemical oxygen demand removal effeciency maximum achieved at the $\mathrm{pH} 7.8$ (Fig. 2). 


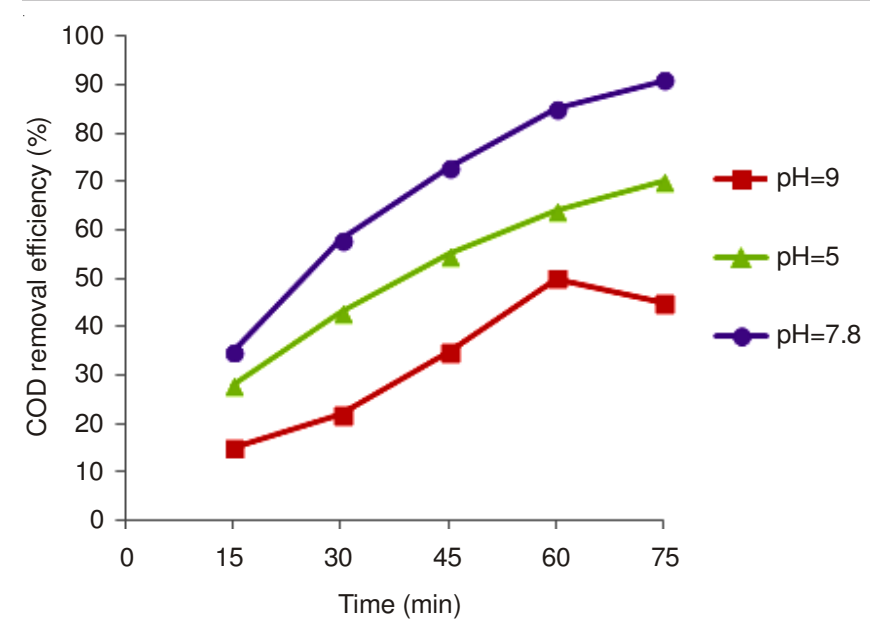

Fig. 2. Effect of $\mathrm{pH}$ of chemical oxygen demand removal by using $\mathrm{Al}$ electrodes

Effect of supporting electrolyte concentration: The chemical oxygen demand effeciency is studied at four different concentration of the electrolyte $\mathrm{Na}_{2} \mathrm{SO}_{4}(0.001,0.025,0.05,0.1$ mol L ${ }^{-1}$ ). All the results (Fig. 3) shows that the effeciency increased as the concentation of the electrolyte decreased. The chemical oxygen demand efficiency decreased from $88 \%$ for 0.001 to $0.1 \mathrm{~mol} \mathrm{~L}^{-1} \mathrm{Na}_{2} \mathrm{SO}_{4}$, as the concentration increased the removal efficiency decreased. This reduction in chemical oxygen demand removal efficiency may be due to the excess of $\mathrm{SO}_{4}^{2-}$ ions, which interact with hydroxyl ions and hindered the corrosion of aluminium electrodes ${ }^{23}$. However, chemical oxygen demand removal decreased with increase in salt concentration. Consequently, excess electrolyte imposed energy demands on the system without any significant effect on the performance (\% chemical oxygen demand removal). To avoid heat generation and high energy consumption, $0.05 \mathrm{~mol} \mathrm{~L}^{-1} \mathrm{Na}_{2} \mathrm{SO}_{4}$ was chosen as the supporting electrolyte concentration for further experiments.

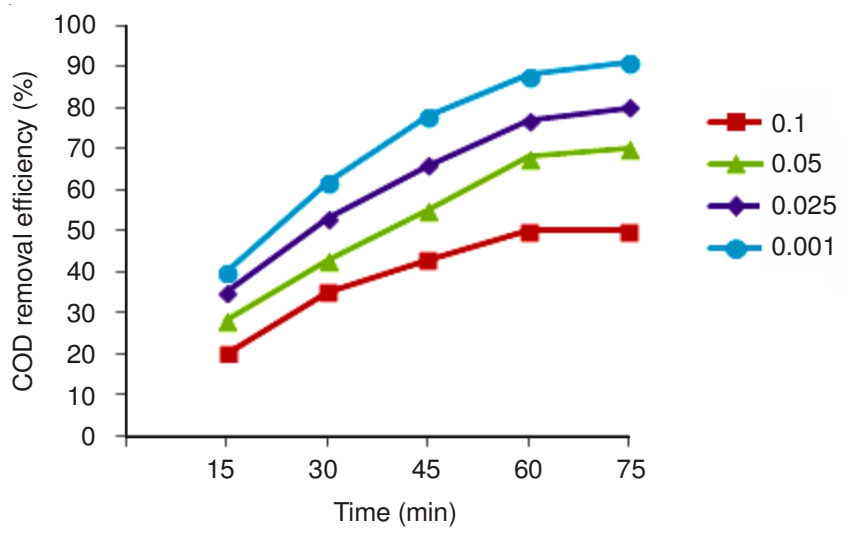

Fig. 3. Effect of electrolyte does on chemical oxygen demand removal by using $\mathrm{Al}$ electrodes

Effect of current density: For the investigation of effect of current density on the chemical oxygen demand removal efficiency, the $\mathrm{pH}$ of sample of slaughter house wastewater was adjusted at 7.8, with $0.001 \mathrm{~mol} \mathrm{~L}^{-1} \mathrm{Na}_{2} \mathrm{SO}_{4}$ as a supporting elec- trolyte. Actually the supply of current to the electrocoagulation system determines the amount of $\mathrm{Al}^{3+}$ ions released from the electrodes and the amount of resulting coagulant. Thus, more $\mathrm{Al}^{3+}$ ions get dissolved into the solution and formation rate of $\mathrm{Al}(\mathrm{OH})_{\mathrm{n}}$ is increased $^{23}$. chemical oxygen demand removal efficiency increased in first $50 \mathrm{~min}$. After $50 \mathrm{~min}$ the current density has negligible effect on removal efficiency as seen in each graph (Fig. 4). The removal efficiency is $90 \%$ when the current density is $2.16 \mathrm{~A} / \mathrm{m}^{2}$, while in case of low current density, chemical oxygen demand removal efficiency started to decrease from $50 \%$. The curve showed that removal efficiency with large amount of current was greater. According to the results obtained from the graphs, the removal efficiencies increased by increasing the current density for aluminium electrodes.

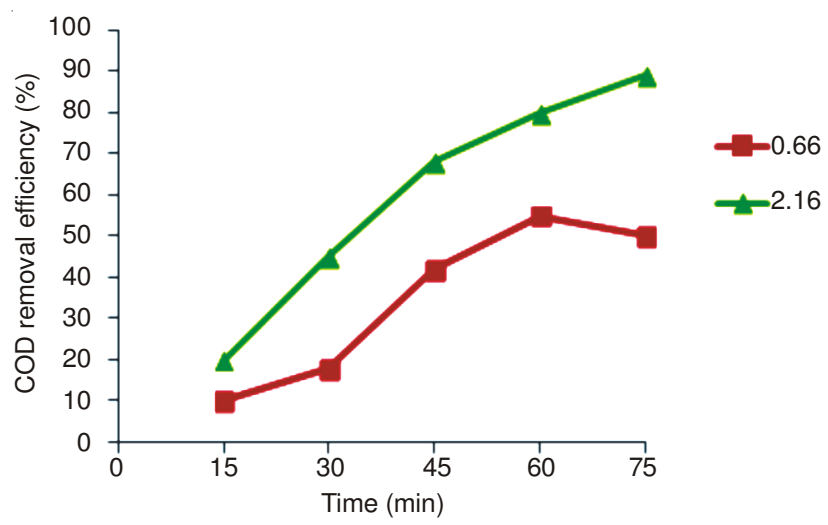

Fig. 4. Effect of current density $\left(\mathrm{A} / \mathrm{m}^{2}\right)$ on chemical oxygen demand removal by using $\mathrm{Al}$ electrodes

\section{Conclusion}

Electrocoagulation is one of the most promising, emerging alternative treatment methods that have more recently been applied for the treatment of slaughter house wastewaters. In this article, the electrochemical treatment of slaughter house wastewater by electrocoagulation using aluminum electrodes was investigated. A series of experiments was performed in order to find the effects of different operational parameters on the removal of chemical oxygen demand and observed that the high chemical oxygen demand removal using aluminium electrode materials at $\mathrm{pH} 7.8$ and current density of $2.16 \mathrm{~A} / \mathrm{m}^{2}$. Different electrocoagulant $\left(\mathrm{Na}_{2} \mathrm{SO}_{4}\right)$ concentrations were used to increase the ionic conductivity of the wastewater. It was found that higher concentration of $\mathrm{Na}_{2} \mathrm{SO}_{4}$ caused a reduction in the removal of chemical oxygen demand from wastewater. So it can be inferred that electrocoagulation is a comparatively suitable process for removal of chemical oxygen demand for the treatment of slaughter house wastewater by using aluminum electrodes.

\section{ACKNOWLEDGEMENTS}

The authors thank the Higher Education Commission, Islamabad, Pakistan for financial support (Grant No. 20-1434/ R\&D/09/9057). 


\section{REFERENCES}

1. O.S. Amuda and A. Alade, Desalination, 196, 22 (2006).

2. H.K. Hansen, P. Nunez and R. Grandon, Miner. Eng., 19, 521 (2006).

3. C.Y. Hu, S.L. Lo, W.H. Kuan and Y.D. Lee, Water Res., 39, 895 (2005).

4. S.H. Lin and C.F. Peng, Water Res., 28, 277 (1994)

5. M. Bayramoglu, M. Kobya, M. Eyvaz and E. Senturk, Sep. Purif. Technol., 51, 404 (2006)

6. A. Alinsafi, M. Khemis, M.N. Pons, J.P. Leclerc, A. Yaacoubi, A. Benhammou and A. Nejmeddine, Chem. Eng. Process., 44, 461 (2005).

7. N. Daneshvar, A. Oladegaragoze and N. Djafarzadeh, J. Hazard. Mater. 129, 116 (2006).

8. O.T. Can, M. Kobya, E. Demirbas and M. Bayramoglu, Chemosphere, 62, 181 (2006)

9. L. Szpyrkowicz, S.N. Kaul, R.N. Neti and S. Satyanarayan, Water Res., 39, 1601 (2005).

10. S.G. Schrank, H.J. Jose, R.F.P.M. Moreira and H.F. Schroder, Chemosphere, 56, 411 (2004).

11. K.S. Min, J.J. Yu, Y.J. Kim and Z. Yun, Subst. Environ. Eng., 39, 1867 (2004).

12. L. Szpyrkowicz, G. H. Kelsall, S. N. Kaul and M. De Faveri, Chem Eng. Sci., 56, 1579 (2001).

13. U. Kurt, O. Apaydin and M.T. Gonullu, J. Hazard. Mater., 143, 33 (2007)

14. Ü. Tezcan Ün, S. Ugur, A.S. Koparal and Ü. Bakir Ögütveren, Sep. Purif. Technol., 52, 136 (2006).

15. N. Adhoum and L. Monser, Chem. Eng. Process., 43, 1281 (2004).

16. H. Inan, A. Dimoglo, H. Simsek and M. Karpuzcu, Sep. Purif. Technol., 36, 23 (2004).

17. M.F. Pouet and A. Grasmick, Water Sci. Technol., 31, 275 (1995).

18. M. Kobya, E. Senturk and M. Bayramoglu, J. Hazard. Mater., 133, 172 (2006)
19. C.T. Tsai, S.T. Lin, Y.C. Shue and P.L. Su, Water Res., 731, 3073 (1990).

20. R. Cossu, A.M. Polcaro, M.C. Lavagnolo, M. Mascia, S. Palmas and F. Renoldi, Environ. Sci. Technol., 32, 3570 (1998).

21. I. Ihara, K. Kanamura, E. Shimada and T. Watanabe, Appl. Superconductivity, 14, 1558 (2004).

22. Y. Deng and J.D. Englehardt, Waste Manag., 27, 380 (2007).

23. Ü. Tezcan Ün, A.S. Koparal and Ü. Bakir Ögütveren, J. Hazard. Mater., 164, 580 (2009).

24. L. Masse and D.I. Masse, Process Biochem., 40, 1225 (2005).

25. A. Torkian, A. Eqbali and S. Hashemian, J. Resour. Conserv. Recycl., 40, 1 (2003).

26. C.E.T. Caixeta, M.C. Cammarota and A.M.F. Xavier, Bioresour. Technol., 81, 61 (2002)

27. M. Merzouki, N. Bernet, J.P. Delgenes and M. Benlemlih, Bioresour. Technol., 96, 1317 (2005).

28. N.Z. Al-Mutairi and M.F. Hamoda, Bioresour. Technol., 95, 115 (2004).

29. F.E. Stuart, Water Sewage, 84, 24 (1946).

30. G. Chen, Separ. Purif. Tech., 38, 11 (2004).

31. P. Ratna Kumar, S. Chaudhari, K.C. Khilar and S.P. Mahajan, Chemosphere, 55, 1245 (2004).

32. M. Khemis, J.-P. Leclerc, G. Tanguy, G. Valentin and F. Lapicque, Chem. Eng. Sci., 61, 3602 (2006).

33. I. Arslan-Alaton, I. Kabdash and Y. Sahin, Open Environ. Biol. Monit. J., 1, 1 (2008).

34. U.T. Un and E. Aytac, J. Environ. Manage., 123, 113 (2013).

35. P. Drogui, M. Asselin, S.K. Brar, H. Benmoussa and J.F. Blais, Sep. Purif. Technol., 61, 301 (2008)

36. J.A.G. Gomes, P. Daida, M. Kesmez, M. Weir, H. Moreno, J.R. Parga, G. Irwin, H. McWhinney, T. Grady, E. Peterson and D.L. Cocke, J. Hazard. Mater., 139, 220 (2007).

37. U. Tezcan Un, A.S. Koparal and U. Bakir Ogutveren, J. Environ. Manage., 90, 428 (2009). 